\title{
Book Review: The Psychology of Family History
}

\author{
Pam Jarvis (D) \\ Institute of Childhood and Education, Leeds Trinity University, Horsforth, Leeds LS18 5HD, UK; \\ p.jarvis@leedstrinity.ac.uk
}

\begin{abstract}
This article reviews The Psychology of Family History. It proposes this as an excellent introductory text for ancestry research, creating a lively discussion of its effects upon individuals and potentially upon communities. The review additionally proposes that the book will be equally useful for academic and independent researchers in the relevant fields.
\end{abstract}

Keywords: family history; psychology; ancestry; identity construction

\section{Review}

As a psychologist who is also a keen ancestry researcher, I expected to enjoy reading this book, and I was not disappointed. Moore et al. (2021) cover the growing popularity of family history/ancestry amongst the general public as well as why current populations have developed a growing interest in genealogy (slight spoiler-the advent of DNA technology forms a crucial part of this), psychological reflections on the impact of genealogical research upon the individual and ethical dilemmas which may arise in the pursuit of such research activities.

The role of religious organisations in the provision of evidence for ancestral research was also an interesting element of the book. This includes some well-considered reflections on the importance of family lineage in some religious traditions and ethical problems that some religious practices may raise-for example, that of baptising the dead.

The "who do you think you are" issue relating to the role of identity in family history research spoke personally to me as a person who started my own research with the idea that I would be principally English with two distant strands of Scottish lineage, but instead found that both paper and DNA trails showed that I was nearly half Scottish, a third continental European, and the remainder mixed Scandinavian, Irish and Kentish English. I was delighted and intrigued by this, and by the resulting reflection that my own strong nonconformist streak may have had its roots in my Scottish Covenantor and dissenting Huguenot ancestors.

However, as the writers point out, not all surprises emerging from ancestry research

Publisher's Note: MDPI stays neutral with regard to jurisdictional claims in published maps and institutional affiliations. are positive. I have personally been aware of an incidence of a mother seeking the man who fathered her child via sperm donation through an ancestry DNA service, culminating in an emphatic message from him that he did not want his current family to be made aware of the child's existence. I have also been involved in a situation in which a woman discovered records of a still-living, unexpected half-sister of her very elderly mother's, with neither woman being aware that the other existed. In both cases, the information was not made available to those who would have been most heavily impacted by it, but through a chain of events in which others had been presented with very difficult choices about what to reveal to whom. These issues are thoroughly discussed in the text, with reference to adoption and forced adoption, with emphasis upon some characteristically Australian experiences of this issue, reflecting the authors' Australian origins.

Some of the topics covered are so new that there is little supporting research evidence to draw upon, such as ancestry research issues raised by the donation of gametes and surrogacy agreements. This sometimes caused the discussion and analysis in the text to 
become somewhat speculative. I also felt that the authors could have extended the analysis of ancestry research through the perspective of identity theory to reduce the heavy reliance upon Ericksonian theory (Orenstein and Lewis 2020). The context of social constructionism (Misra and Prakash 2012) would have lent an interesting angle to this analysis in terms of how we construct our personal identities in flexible ways, which are likely to be enhanced by the addition of knowledge about our unique ancestral combinations. For example, the synthesis of my own genealogical blending of a potent mixture of ancestral dissenters discussed above is a very personal take. Others with the same combination of genes might create many different narratives from the same information.

The impact upon stories that we tell about ourselves from the perspective of revealed family history would be a fascinating research topic in itself. However, as far as I am aware, it has not been covered in currently available academic publications. This takes the book to the crux of its dilemma-the newness of the popular ancestry fascination and the recency of the DNA component (Royal et al. 2010), resulting in sparsity of underpinning academic literature. As such, this led the last third of the book in particular to making a significant amount of speculative commentary, which is nevertheless interesting in itself-for example, the potential benefits and drawbacks of engagement in ancestry research.

The authors make some useful suggestions relating to the use of ancestry research in demonstrating to children that they have roots within a genetic and cultural heritage and in helping grandparents to feel that they are leaving a legacy for their descendants, and in documenting much loved relatives who have been dead for some time to permit them to "live" to some extent in the minds of their descendants.

As a family researcher who took one of her ancestral family stories into a novel, I can also relate to the drawbacks the authors suggest: the temptation to live more in the past than the present, and the overwhelming sadness created by the knowledge of some of the plights in which ancestors found themselves, particularly those that could be much more easily solved in the present, which is one of the key themes of the novel in question.

The authors make some salient suggestions for the use of ancestry research in therapy for grief and raise the possibility that ancestry research may usefully cross the family/formal history research barrier as a pedagogic device to render people in history more relatable to schoolchildren as fellow human beings. I have personal experience of this process too, having many years ago taken in a photograph of my long dead grandfather as a child to talk to my children's primary class about Victorians. A child in the class pointed out that my grandfather looked very similar to my son "dressed up" and stated that therefore he was now convinced that Victorians must have been "real".

I would add to this that through such study, children could also discover immigrant heritage of which they were previously unaware, which could be used as a thinking tool to reduce discrimination and prejudice against more recent immigrants. For example, I experienced a powerful reflection on this point when I discovered that the word "refugee" passed into English through my Huguenot ancestors' language.

In summary, there is a lot to recommend this book to anyone who wants to learn a little more about ancestry research, its effects upon researchers and potentially, the wider community. Its only downfall is that, sometimes, the underpinning research is somewhat sparse, meaning that consequently, the text begins to move into a rather speculative arena. However, on the other hand, the book is written in a format that makes it an excellent candidate for the nonacademic ancestry interest market. It is an easy, absorbing read and its terminology will be easily grasped by hobbyist family researchers, who I am sure would find its contents highly interesting and informative.

Institutional Review Board Statement: Not applicable.

Informed Consent Statement: Not applicable.

Data Availability Statement: Not applicable.

Conflicts of Interest: The author declares no conflict of interest. 


\section{References}

Misra, Girishwar, and Anand Prakash. 2012. Kenneth J. Gergen and Social Constructionism. Psychological Studies 57: 121-25. Available online: https:/ /link.springer.com/article/10.1007/s12646-012-0151-0\#citeas (accessed on 25 February 2021).

Moore, Susan, Doreen Rosenthal, and Rebecca Robinson. 2021. The Psychology of Family History. Abingdon: Routledge.

Orenstein, Gabriel, and Lindsay Lewis. 2020. Erickson's Stages of Psychosocial Development. In StatPearls. Available online: https: / / www.ncbi.nlm.nih.gov/books/NBK556096/ (accessed on 25 February 2021).

Royal, Charmaine D., John Novembre, Stephanie M. Fullerton, David B. Goldstein, Jeffrey C. Long, Michael J. Bamshad, and Andrew G. Clark. 2010. Inferring Genetic Ancestry: Opportunities, Challenges, and Implications. American Journal of Human Genetics 86: 661-73. Available online: https:/ / www.ncbi.nlm.nih.gov/pmc/articles/PMC2869013/ (accessed on 25 February 2021). 